\title{
The influence of Kyokushinkai Karate classes on the adaptive capabilities of adolescents
}

\author{
Kyrpenko Y.V. ${ }^{1}$, Budur M.I., ${ }^{2}$, Palevych S.V., ${ }^{3}$, Poddubny O.G. ${ }^{4}$ \\ ${ }^{2,3,4}$ Ivan Kozhedub Kharkiv National University of the Air Force, Kharkiv \\ ${ }^{1}$ Taras Shevchenko Lugansk National University, Starobilsk,Ukraine
}

DOI: https://doi.org/10.34142/HSR.2019.05.04.06

\section{Abstract}

The purpose of the work: to determine the impact of Kyokushinkai Karate classes on the ability to adapt to different physical activities of boys of 10-12 years of age during classes.

Material and methods. 78 boys of 10-12 years were surveyed, 27 of them expressed their desire to participate in the sports section of Kyokushinkai Karate (EG). CG (29) includes guys who do not have contraindications for playing sports. The essence of the forming experiment was to compare the growth rates of individual indicators of physical qualities, functional preparedness of children who attended the Kyokushinkai Karate training program (experimental group - EG) with children who were engaged in physical education only during physical culture lessons (control group - CG). During the year a monitoring examination of children is carried out to assess physical development, adaptation to exercise, adaptive potential of the circulatory system, the functional state of the apparatus of external respiration, the energy potential of the organism, physical fitness and methods of mathematical statistics.

Results. The plan of preparation of training groups on the basis of rational sequence of use of a set and volume of means and methods of physical education of normative part of the curriculum "Kyokushinkai Karate" is presented. Adaptation processes occurring in the body of boys, during the acquisition of knowledge and skills within the walls of the school are determined by a number of educational, behavioral, everyday and other factors, each of which has a specific purposefulness to achieve a useful end result of learning. The course of study at school is undoubtedly accompanied by the adaptation of children to the new mode of study, rest, psychological and physical activity, and the question of the dynamics of indicators of functional systems of the child's organism came to the plane of our research.

Conclusion. In the course of the research, we came to the conclusion that the plan developed and implemented in the sports circles improves the adaptation capabilities of the boys of this age group during Kyokoshinkai karate classes. Key words: Kyokushinkai Karate; physical activities; sport

\section{Анотація}

Кирпенко Є.В., Будур М.І., Палевич С.В., Піддубний О.Г. Вплив занять кіокушинкай карате на адаптаційні можливості підлітків

Мета роботи: визначити вплив занять кіокушинкай карате на здатність адаптуватися до різних фізичних навантажень хлопчиків 10-12 років.

Матеріал і методи. Обстежено 78 хлопчиків 10-12 років, 27 з них виявили бажання брати участь в спортивній секції кіокушинкай карате (ЕГ). КГ (29) включала хлопчиків, у яких немає протипоказань до занять спортом. Суть формуючого експерименту полягала в зіставленні темпів зростання індивідуальних показників фізичних якостей, функціональної підготовленості дітей, які відвідували програму навчання кіокушинкай карате (експериментальна група - ЕГ), з дітьми, які займалися фізкультурою тільки на уроках фізичної культури (контрольна група - КГ). Протягом року проводиться моніторингове обстеження дітей з метою оцінки фізичного розвитку, адаптації до фізичного навантаження, адаптаційного потенціалу системи кровообігу, функціонального стану апарату зовнішнього дихання,

енергетичного потенціалу організму, фізичної підготовленості.

Результати. Представлений план підготовки навчальних груп на основі раціональної послідовності використання набору та обсягу засобів і методів фізичного виховання нормативної частини навчального плану «Кіокушинкай карате». Процеси адаптації, що відбуваються в організмі хлопчиків при придбанні знань і навичок в стінах школи, визначаються рядом освітніх, поведінкових, побутових та інших факторів, кожен з яких має особливу цілеспрямованість для досягнення корисного кінцевого результату. навчання. Курс навчання в школі, безсумнівно, супроводжується адаптацією дітей до нового режиму навчання, відпочинку, психологічної та фізичної активності, і питання динаміки показників функціональних систем організму дитини вийшов на план нашого дослідження.

Висновок. В ході дослідження ми прийшли до висновку, що план, розроблений і впроваджений в спортивних колах, покращує адаптаційні можливості хлопчиків цієї вікової групи на уроках кіокошінкай карате. Ключові слова: кіокушинкай карате; фізичні вправи; спорт

\section{Аннотация}

Кирпенко Е.В., Будур М.И., Палевич С.В., Поддубный А.Г. Влияние занятий киокушинкай каратэ адаптационные возможности подростков

Цель работы: определить влияние занятий киокушинкай каратэ на способность адаптироваться к различным физическим нагрузкам мальчиков 10-12 лет.

Материал и методы. Обследовано 78 мальчиков 10-12 лет, 27 из них изъявили желание участвовать в спортивной секции киокушинкай каратэ (ЭГ). КГ (29) включала мальчиков, у которых нет противопоказаний к занятиям спортом. Суть формирующего эксперимента заключалась в сопоставлении темпов роста индивидуальных показателей физических качеств, функциональной подготовленности детей, которые посещали программу обучения киокушинкай каратэ (экспериментальная группа - ЭГ), с детьми, которые занимались физкультурой только на уроках физической культуры (контрольная группа - КГ). В течение года проводится мониторинговое обследование детей с целью оценки физического развития, адаптации к физической нагрузке, адаптационного потенциала системы кровообращения, функционального состояния аппарата внешнего дыхания, энергетического потенциала организма, физической подготовленности.

Результаты. Представлен план подготовки учебных групп на основе рациональной последовательности использования набора и объема средств и методов физического воспитания нормативной части учебного плана «Киокушинкай каратэ». Процессы адаптации, происходящие в организме мальчиков при приобретении знаний и навыков в стенах школы, определяются рядом образовательных, поведенческих, бытовых и других факторов, каждый из которых имеет особую целенаправленность для достижения полезного конечного результата. обучения. Курс обучения в школе, несомненно, сопровождается адаптацией детей к новому режиму учебы, отдыха, психологической и физической активности, и вопрос динамики показателей функциональных систем организма ребенка вышел на план нашего исследования.

Вывод. В ходе исследования мы пришли к выводу, что план, разработанный и внедренный в спортивных кругах, улучшает адаптационные возможности мальчиков этой возрастной группы на уроках киокошинкай каратэ. Ключевые слова: киокушинкай каратэ; физические упражнения; спорт 


\section{Introduction}

One of the main tasks of the curriculum of physical education and sports in the field of extracurricular education is the installation of comprehensive personality development. The criterion for assessing the complex effect of exercise on educational activity is the degree of development of adaptive capabilities of the child, which is reflected in the level of health $[1,2,3]$. Scientific studies show that a large number of children entering the first grade have low performance. It is known that good success with insufficient functional readiness of the organism is achieved by considerable stresses of its various systems, which can lead to disorders of the nervous and mental sphere of the child and to poor health.

The results of scientific studies indicate a significant expansion of human adaptive capabilities through regular use and correct dosage of physical exercises [3]. Moreover, the effectiveness of physical training is significantly due to age factor $[4,5]$.

Adaptation capabilities of a person are also characterized by the quality of adaptation to physical activity of different directions during training in a sports circle. Therefore, an objective criterion for assessing these opportunities in adolescents may be their ability to demonstrate functional and physical fitness in the context of learning the requirements of the Kyokushinkai Karate training program. Thus, the study of the importance of Kyokushinkai karate exercises for increasing the adaptation of adolescents to physical activity of different directions will allow to expand the modern ideas about the possibilities of improving physical health by means of physical culture.

The purpose of the work: to determine the impact of Kyokushinkai Karate classes on the ability to adapt to different physical activities of boys of 10-12 years of age during classes.

\section{Material and methods}

\section{Participants}

Our research was conducted at the secondary school №45 in Kharkiv. 78 boys of 10-12 years were surveyed, 27 of them expressed their desire to participate in the sports section of Kyokushinkai Karate (EG). CG (29) includes guys who do not have contraindications for playing sports. To determine the impact of karate training on the adaptive capabilities of adolescents to exercise and to obtain information on what were the actual results of the educational process, the level of training, whether they have deviations, in the EG and CG at the beginning (input control) of the formative pedagogical experiment and at the end of the experimental study (in a year - baseline control) the measurement and analysis of the data were carried out. When comparing the indicators in the boys of both groups, we found no statistically significant differences $(p>0.05)$. Throughout the experimental period, classes were held with the $\mathrm{CG}$ representatives in accordance with the Physical Education Curriculum [5], with EGs under the Kyokushinkai Karate Curriculum [6].

\section{Procedure}

The methodological bases of the developed plan for preparation for the karate training program included:

determining the ratio of the means of general, special physical and technical training;

selection and determination of rational orientation of the means of general and special physical training;

substantiation of the basic methods of performance of exercises. An approximate ratio of the means of physical, technical training for the branches of kyokushushkay karate are presented in table 1.

Table 1

The ratio of the means of physical and technical training by years of study

\begin{tabular}{lcc}
\hline & First year & Second year \\
\hline General physical fitness & $65 \%$ & $40 \%$ \\
\hline Special physical fitness & $5 \%$ & $15 \%$ \\
\hline Technical training & $30 \%$ & $45 \%$ \\
\hline
\end{tabular}


The main means of training effects:

- general development exercises (for the purpose of creating a traffic school);

- moving games and game exercises 3 . elements of acrobatics (tipping, turns, squats, etc.);

- all sorts of jumps and jumping exercises;

- throwing light shells (tennis and stuffed balls);

- sports-strength exercises (in the form of complexes of training tasks).

The basic methods of performance of exercises: game, repeated, uniform, competitive (in control and pedagogical tests).

\section{Experimental protocol}

In this research, we used accessible, informative, non-invasive research methods to reach large groups of children over a short period. (during obligatory medical preventive examinations of students (Order of the Ministry of Health of Ukraine of August 16, 2010 No. 682) [7]. Assessment of physical development was carried out by comparing anthropometric (length and body weight) with indicators of age and regional standards using the classical method.

Body length or standing height is measured using a height meter. Body weight is determined by weighing on medical scales without shoes in a tracksuit. The degree of harmony of physical development and physique was determined by the mass-growth index of Ketle [8].

The Ruffier index is used to determine load adaptation, which is widely used in mass surveys of schoolchildren [9].

Adaptation potential of the circulatory system (in points) was estimated by the Bayevsky method

The functional state of the external respiration apparatus was evaluated by the Stange test and the Genchi test.

To quantify the energy potential of the human body, the reserve index - "double product" (DP) - Robinson index is used.

Assessment of physical fitness was carried out during the annual compulsory assessment of pupils of educational institutions in accordance with the instruction on the organization of the annual assessment of physical fitness of the population of Ukraine.

Development level:

- endurance and resistance to moderate loads was evaluated by running 1000 meters;

- arm strength - pull-up on the crossbar;

-leg strength - long jump from place;

- agility - shuttle running 4 x $9 \mathrm{~m}$;

-flexibility - body leaning forward from sitting position.

\section{Statistical analysis}

In mathematical processing of the primary materials of this study, in addition to the calculation of primary statistics, a comparative analysis of the students' averag t-test was carried out. To compare the parts expressed as a percentage, we used the multifunctional Fisher criterion $\varphi$ (Fisher angular transformation) [9].

\section{Results}

The level of physical fitness of the boys was determined by comparing the results of testing with the normative indicators presented in the curriculum "Physical Education (5-9 classes)" (approved by the Ministry of Education of Ukraine from October 23, 2017 № 1407) [10], as well as the State Testing System of Ukraine [11, 12]. In EG, 6 boys left the section for various reasons, so their results were excluded from the statistical calculations.

According to the results of the experimental (initial) control, it was established (Table 2) that the average level of anthropometric indicators of the CG and EG compared to the experimental state underwent significant changes $(p<0.001)$. The difference in body growth rates was $3.34 \%(\mathrm{t}=9.97)$ in CG and $4.14 \%(\mathrm{t}=15.77)$ in EG. Body weight increased significantly in both groups by 16.64 and $10.18 \%$ respectively. Such dynamics can be explained by age-related changes in the child's body.

In Fig. 1 presents the results of the analysis of the diversity of indicators of input control data on the degree of harmony of physical development and physique of boys CG and EG before the experiment, which confirmed statistically significant homogeneity ( $p>0.05$ ) of the sample groups by the percentage of boys in them with different body mass index 
Dynamics of anthropometric indicators in boys CG $(n=29)$ and $E G(n=21)$ by the results of forming experiment (2018-2019)

\begin{tabular}{|c|c|c|c|c|c|c|c|c|c|}
\hline \multirow{3}{*}{$\begin{array}{l}\text { Indicators } \\
\text { (unit of } \\
\text { measure) }\end{array}$} & \multirow{3}{*}{$\begin{array}{l}\text { Research } \\
\text { period }\end{array}$} & \multirow{3}{*}{ Group } & \multirow{3}{*}{$\bar{X}$} & \multirow{3}{*}{$S$} & \multirow{3}{*}{$\mathrm{m}$} & \multirow{3}{*}{$\begin{array}{c}\text { Changes, } \\
\%\end{array}$} & \multirow{2}{*}{$B E-A E$} & \multicolumn{2}{|c|}{ CG-EG } \\
\hline & & & & & & & & $\mathrm{BE}$ & $\mathrm{AE}$ \\
\hline & & & & & & & $\mathrm{t}$ & $\mathrm{t}$ & $\mathrm{t}$ \\
\hline \multirow{4}{*}{$\begin{array}{l}\text { Body height } \\
\text { (cm) }\end{array}$} & $\mathrm{BE}$ & \multirow{2}{*}{ CG } & 147.24 & 41.40 & 1.19 & \multirow{2}{*}{3.34} & \multirow{2}{*}{$9.97^{* * *}$} & \multirow{4}{*}{0.75} & \multirow{4}{*}{0.154} \\
\hline & $\mathrm{AE}$ & & 152.16 & 50.66 & 1.32 & & & & \\
\hline & $\mathrm{BE}$ & \multirow{2}{*}{ EG } & 145.30 & 42.83 & 1.26 & \multirow{2}{*}{4.14} & \multirow{2}{*}{$15.77^{* * *}$} & & \\
\hline & $\mathrm{AE}$ & & 151.85 & 46.04 & 1.48 & & & & \\
\hline \multirow{4}{*}{$\begin{array}{l}\text { Body weight } \\
\text { (kg) }\end{array}$} & $\mathrm{BE}$ & \multirow{2}{*}{ CG } & 33.83 & 40.43 & 1.18 & \multirow{2}{*}{16.64} & \multirow{2}{*}{$8.17^{* * *}$} & \multirow{4}{*}{0.71} & \multirow{4}{*}{0.81} \\
\hline & $\mathrm{AE}$ & & 39.46 & 24.74 & 0.92 & & & & \\
\hline & $\mathrm{BE}$ & \multirow{2}{*}{ EG } & 35.79 & 22.18 & 0.91 & \multirow{2}{*}{10.18} & \multirow{2}{*}{$13.65^{* * *}$} & & \\
\hline & $\mathrm{AE}$ & & 38.46 & 8.85 & 0.65 & & & & \\
\hline
\end{tabular}

Note: $\mathrm{BE}$ - before the experiment, $\mathrm{AE}-$ after the experiment

$* * *-$ The differences are significant at $p<0.001$

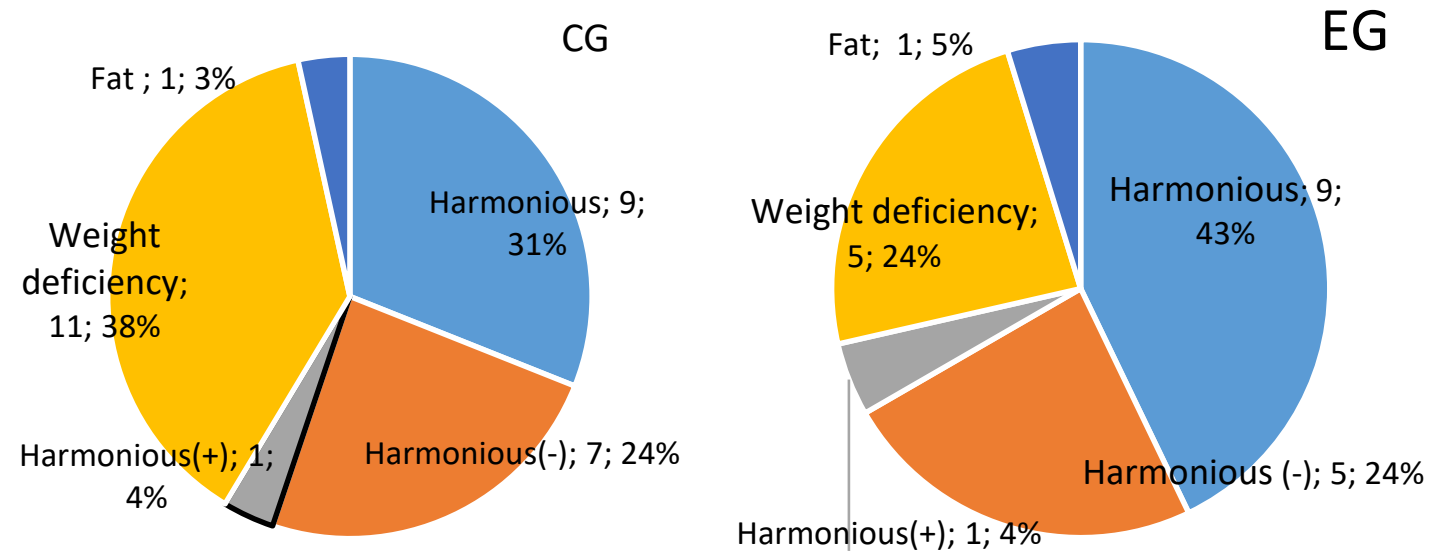

Fig. 1. Degree of harmony of physical development and physique of boys CG and EG before experiment

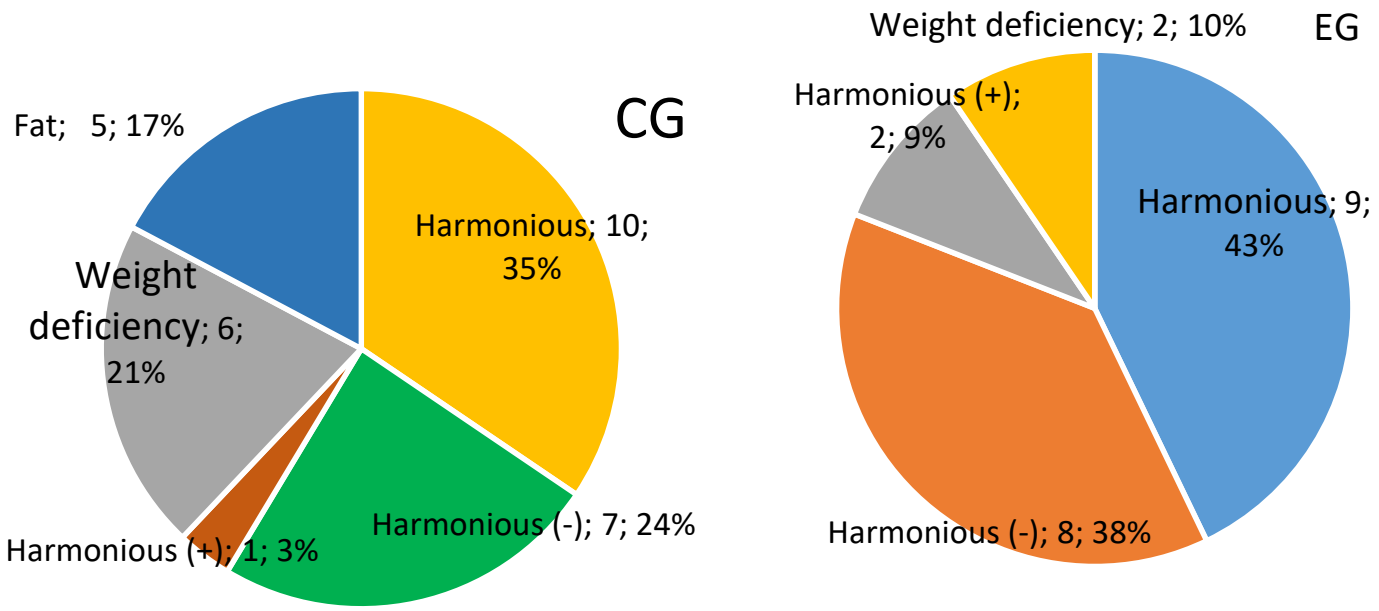

Fig. 2. Degree of harmony of physical development and physique of boys of CG and EG after experiment 
Adequate dynamic anthropometric observation of the physical development of boys (Fig. 2) revealed the absence of EG boys with obese physique, and CG observed an increase of 4 boys.

The results of monitoring the dynamics of boys' functional readiness by the results of the forming experiment are given in Table 3. The level of functional status of the respiratory system of boys of the studied samples was determined by conducting breath-hold breath tests - Stange and breath-hold breath - Gencha (Table 3). According to the results of the experimental control, it was established (Table 3) that the level of the functional state of the respiratory system of representatives of the $\mathrm{CG}$ and EG compared to the experimental period underwent an overall positive dynamics. cadets is:

The rate of increase of these indicators in CG

Stange trial $-1.63 \%(\mathrm{p}=0.574$ at $\mathrm{t}=0.57)$;

Gencha trial $-1.38 \%(\mathrm{p}=0.8 \mathrm{c}$ at $\mathrm{t}=0.25)$.

The EG boys have a significant increase in indicators and are:

Stange trial $-10.54 \%(\mathrm{p}=0.033$ at $\mathrm{t}=2,28) ;$

Gencha trial $-12,36 \%(\mathrm{p}=0.031 \mathrm{c}$ at $\mathrm{t}=$ $2,31)$. The results of cardio-vascular system study are presented in Table 3. A heart rate measurement showed that in children as CG, such EG is followed by a decrease in heart rate (in CG boys, the rate of decrease is $1 \%$, and in boys EG, the rate of decrease is $1.41 \%)$. It should be noted that this difference is statistically significant both in CG $(\mathrm{p}=0.015$ at $\mathrm{t}=$ $2.588)$ and in boys $E G(p=0.001$ at $t=3.724)$. The maximum and minimum values of heart rate differ little. Thus, in CG boys, maximum values are 96-100 bpm, minimum 80-77 bpm, in EG - 104-88 bpm, 77 72 bpm, respectively. There was a significant difference in $\mathrm{HR}$ and at the end of the experiment $(\mathrm{p}$ $<0.001$ at $\mathrm{t}=4.81$ )

The level of adaptation to load (Ruffier index) in both groups is estimated as average. But in CG there is a decrease in 4 guys above average to average and increase in one from average to above average, and in 3 from below average to average. One boy raised his low to average. There are also changes in the EG. Two guys who had high and above average lowered their level to average, 4 raised from average to above average, from below average 2 were raised to average and 2 were above average. One boy raised his low to average.

Dynamics of functional parameters boys CG $(n=29)$ and EG $(n=21)$ the results of forming experiment $(2018-2019)$

\begin{tabular}{|c|c|c|c|c|c|}
\hline $\begin{array}{c}\text { Indicators (unit of } \\
\text { measure) }\end{array}$ & Research period & Group & $\bar{X}$ & $S$ & $\mathrm{~m}$ \\
\hline \multirow{4}{*}{ HRrest (bpm) } & $\mathrm{BE}$ & \multirow{2}{*}{ CG } & 88.00 & 5.01 & 0.93 \\
\hline & $\mathrm{AE}$ & & 87.1 & 4.04 & 0.75 \\
\hline & $\mathrm{BE}$ & \multirow{2}{*}{ EG } & 86.47 & 8.34 & 1.82 \\
\hline & $\mathrm{AE}$ & & 82.14 & 3.24 & 0.71 \\
\hline \multirow{4}{*}{$\begin{array}{l}\text { Ruffier Index } \\
\text { (con. units) }\end{array}$} & $\mathrm{BE}$ & \multirow{2}{*}{ CG } & 11.75 & 3.16 & 0.59 \\
\hline & $\mathrm{AE}$ & & 10.96 & 1.94 & 0.36 \\
\hline & $\mathrm{BE}$ & \multirow{2}{*}{ EG } & 11.42 & 4.74 & 0.90 \\
\hline & $\mathrm{AE}$ & & 8.67 & 2.21 & 0.48 \\
\hline \multirow{4}{*}{$\mathrm{SBP}(\mathrm{mmHg})$} & $\mathrm{BE}$ & \multirow{2}{*}{ CG } & 104.62 & 6.72 & 1.25 \\
\hline & $\mathrm{AE}$ & & 106.14 & 7.05 & 1.31 \\
\hline & $\mathrm{BE}$ & \multirow{2}{*}{ EG } & 103.95 & 6.48 & 1.41 \\
\hline & $\mathrm{AE}$ & & 105.48 & 8.17 & 1.78 \\
\hline \multirow{4}{*}{$\mathrm{DBP}(\mathrm{mmHg})$} & $\mathrm{BE}$ & \multirow{2}{*}{ CG } & 69.83 & 7.07 & 1.31 \\
\hline & $\mathrm{AE}$ & & 70.3 & 6.4 & 1.19 \\
\hline & $\mathrm{BE}$ & \multirow{2}{*}{ EG } & 69.1 & 8.17 & 1.57 \\
\hline & $\mathrm{AE}$ & & 69.43 & 7.42 & 1.62 \\
\hline \multirow{4}{*}{$\begin{array}{l}\text { Adaptation potential of the } \\
\text { circulatory system (in } \\
\text { points) }\end{array}$} & $\mathrm{BE}$ & \multirow{2}{*}{ CG } & 1.85 & 0.01 & 0.02 \\
\hline & $\mathrm{AE}$ & & 1.9 & 0.16 & 0.03 \\
\hline & $\mathrm{BE}$ & \multirow{2}{*}{ EG } & 1.85 & 0.02 & 0.03 \\
\hline & $\mathrm{AE}$ & & 1.84 & 0.16 & 0.03 \\
\hline \multirow{4}{*}{ Stange trial (s) } & $\mathrm{BE}$ & \multirow{2}{*}{ CG } & 49.59 & 6.01 & 1.12 \\
\hline & $A E$ & & 50.05 & 1.67 & 0.31 \\
\hline & $\mathrm{BE}$ & \multirow{2}{*}{ EG } & 49.96 & 9.69 & 1.80 \\
\hline & $\mathrm{AE}$ & & 54.83 & 2.08 & 0.45 \\
\hline
\end{tabular}




\begin{tabular}{|c|c|c|c|c|c|}
\hline \multirow{4}{*}{ Gencha trial (s) } & $\mathrm{BE}$ & \multirow{2}{*}{ CG } & 23.97 & 3.31 & 0.61 \\
\hline & $\mathrm{AE}$ & & 24.09 & 0.85 & 0.16 \\
\hline & $\mathrm{BE}$ & \multirow{2}{*}{ EG } & 24.26 & 5.19 & 1.13 \\
\hline & $\mathrm{AE}$ & & 26.87 & 0.79 & 0.17 \\
\hline \multirow{4}{*}{$\begin{array}{l}\text { The Robinson Index (con. } \\
\text { units) }\end{array}$} & $\mathrm{BE}$ & \multirow{2}{*}{ CG } & 92.13 & 8.67 & 1.6 \\
\hline & $\mathrm{AE}$ & & 93.45 & 8.23 & 1.53 \\
\hline & $\mathrm{BE}$ & \multirow{2}{*}{ EG } & 89.64 & 7.49 & 1.64 \\
\hline & $\mathrm{AE}$ & & 87.43 & 7.16 & 1.56 \\
\hline \multirow{4}{*}{ Kettle Index $\left(\mathrm{kg} / \mathrm{m}^{2}\right)$} & $\mathrm{BE}$ & \multirow{2}{*}{ CG } & 15.64 & 6.86 & 0.49 \\
\hline & $\mathrm{AE}$ & & 17.10 & 5.57 & 0.44 \\
\hline & $\mathrm{BE}$ & \multirow{2}{*}{ EG } & 17.00 & 5.13 & 0.44 \\
\hline & $\mathrm{AE}$ & & 16.71 & 1.66 & 0.28 \\
\hline
\end{tabular}

Note: CG - control groop; EG - experimental groop

It should be noted that all researchers report an increase in blood pressure with age, which is more noticeable for systolic pressure (from birth to 20 years increases in guys by an average of $2 \mathrm{~mm} \mathrm{Hg}$ per year than for diastolic (gain about $0.5 \mathrm{~mm} \mathrm{Hg}$ for the year) [13]. The average SBP values in CG boys were $106.14 \pm 1.31 \mathrm{~mm} \mathrm{Hg}$ after the experiment, in the EC $-105,48 \pm 1.41 \mathrm{~mm} \mathrm{Hg}$. (Table 3). The maximum values of the upper limit of blood pressure in boys with CG were in the range of 96-120 $\mathrm{mm} \mathrm{Hg}$. In EG, maximum SBP values range from 95 to 115 $\mathrm{mm} \mathrm{Hg}$. The obtained results give grounds to claim that the students of CG and EG have a wave-like fluctuation in the magnitude of systolic pressure in the direction of increase or decrease. Comparing diastolic blood pressure with average, we note that in boys CG and EG, an increase in pressure (70.3 $\mathrm{mmHg}-69.43 \mathrm{mmHg}$ ) is observed.

Adaptation processes occurring in the body of boys, during the acquisition of knowledge and skills within the walls of the school are determined by a number of educational, behavioral, everyday and other factors, each of which has a specific purposefulness to achieve a useful end result of learning. The course of study at school is undoubtedly accompanied by the adaptation of children to the new mode of study, rest, psychological and physical activity, and the question of the dynamics of indicators of functional systems of the child's organism came to the plane of our research.

Taking into account that the indicator of adaptation potential accurately characterizes the level of adaptation of the organism of children to new factors of the learning environment, and its main components are indicators of human health, we quantified the level of adaptation potential of the system according to anthropometric status and functioning circulation of boys of the studied groups (Table 3) according to the equation developed by P. Baevsky and co-authors [14].
Comparing the level of adaptation of the organism of boys of the studied groups to new factors of the learning environment, we determined its advantage by 0.06 c.u. (see table 3 ) in the EG boys, based on the results of the annual experimental work. The percentage of representatives whose organism was in a state of "tension of adaptation mechanisms" after the experiment changed in the CG from $3.4 \%$ to $17.2 \%$, and the representatives of the EG remained unchanged as it was at the beginning of the experiment.

Comparing the level of functional capacity of the muscles of the heart according to the PD, a significant advantage of the maximum aerobic capacity in boys EG was determined $(\mathrm{p}=0.01$ at $\mathrm{t}=$ 2.69).

By the level of development of general physical qualities, acquisition of motor skills by the CG and EG boys, the results of the input and output controls showed a significant difference in the effectiveness of the school and program of sports section of Kyokushinkai karate.

Thus, according to the results of obtaining at the school of education by the CG boys according to the traditional training program with PT and according to the program of sports section of Kyokushinkai Karate, there is a significant improvement in indicators of strength and speedpower qualities (Table 4.6) $(\mathrm{p}<0.001)$ with uniform and low tempo development (in boys CG $-10.5 \%$ and $1.78 \%$; in EG $-9.84 \%$ and $3.05 \%$ ). The average mark in the pull-up on the CG bar is 3.62 points, in the long jump from the place - 4.1 points. In EG, the average mark in the pull-up on the crossbar is 3.47 points, in the long jump from the place -3.9 points.

The results of the study indicate that the test results "shuttle running $4 \times 9 \mathrm{~m}$ " and "leaning the torso forward from a sitting position" have significantly high rates of development in both groups ( $\mathrm{p}<0.001)$.

Our results of testing of coordination abilities testify to above average level in all groups (in boys EG - 3,8 and CG - 3,4 points). However, 
there is a statistical difference $(\mathrm{p}=0.047 ; \mathrm{t}=2.04)$ between the results of the CG and EG boys at the end of the first year of employment (Table.6)

The level of development of flexibility corresponds to the average and sufficient levels according to the State system of tests of Ukraine. Year-on-year growth in CG boys was $11.08 \%$; in EG - 59,57\%, which has a significant difference $(\mathrm{p}=$ $0.026 ; \mathrm{t}=2,31)$.

Dynamics of indicators of general physical qualities in boys CG $(n=29)$ and $E G(n=21)$ by the results of the forming experiment (2018-2019)

\begin{tabular}{|c|c|c|c|c|c|c|c|c|c|}
\hline \multirow{3}{*}{$\begin{array}{l}\text { Indicators (unit } \\
\text { of measure) }\end{array}$} & \multirow{3}{*}{$\begin{array}{l}\text { Research } \\
\text { period }\end{array}$} & \multirow{3}{*}{ Group } & \multirow{3}{*}{$\bar{X}$} & \multirow{3}{*}{$\mathrm{S}$} & \multirow{3}{*}{$\mathrm{m}$} & \multirow{3}{*}{$\begin{array}{c}\text { Changes, } \\
\%\end{array}$} & \multirow{2}{*}{$B E A E$} & \multicolumn{2}{|c|}{ CG-EG } \\
\hline & & & & & & & & $\mathrm{BE}$ & $\mathrm{AE}$ \\
\hline & & & & & & & $\mathrm{t}$ & $\mathrm{t}$ & $\mathrm{t}$ \\
\hline \multirow{4}{*}{$1000 m$ run (s) } & $\mathrm{BE}$ & \multirow{2}{*}{ CG } & 352.24 & 16.23 & 3.01 & \multirow{2}{*}{0.03} & \multirow{2}{*}{0.014} & \multirow{4}{*}{0.37} & \multirow{4}{*}{$2.19 *$} \\
\hline & $\mathrm{AE}$ & & 352.25 & 18.87 & 3.50 & & & & \\
\hline & $\mathrm{BE}$ & \multirow{2}{*}{ EG } & 350.52 & 21.96 & 4.79 & \multirow{2}{*}{3.1} & \multirow{2}{*}{$44.95^{* * *}$} & & \\
\hline & $\mathrm{AE}$ & & 339.56 & 21.22 & 4.63 & & & & \\
\hline \multirow{4}{*}{$\begin{array}{l}\text { Pulling on the } \\
\text { crossbar (count) }\end{array}$} & $\mathrm{BE}$ & \multirow{2}{*}{ CG } & 5.21 & 2.77 & 0.51 & \multirow{2}{*}{10.5} & \multirow{2}{*}{$10.12^{* * *}$} & \multirow{4}{*}{0.37} & \multirow{4}{*}{0.37} \\
\hline & $\mathrm{AE}$ & & 5.81 & 3.09 & 0.57 & & & & \\
\hline & $\mathrm{BE}$ & \multirow{2}{*}{ EG } & 4.9 & 3.02 & 0.59 & \multirow{2}{*}{9.84} & \multirow{2}{*}{$7.45^{* * *}$} & & \\
\hline & $\mathrm{AE}$ & & 5.47 & 3.36 & 0.73 & & & & \\
\hline \multirow{4}{*}{$\begin{array}{l}\text { Long jump from } \\
\text { place }(\mathrm{cm})\end{array}$} & $\mathrm{BE}$ & \multirow{2}{*}{ CG } & 158.69 & 18.93 & 3.51 & \multirow{2}{*}{1.78} & \multirow{2}{*}{$45.14^{* *}$} & \multirow{4}{*}{1.02} & \multirow{4}{*}{0.622} \\
\hline & $\mathrm{AE}$ & & 161.55 & 19.27 & 3.58 & & & & \\
\hline & $\mathrm{BE}$ & & 153.76 & 13.21 & 2.88 & & & & \\
\hline & $\mathrm{AE}$ & EG & 158.5 & 13.39 & 2.92 & 3.05 & $38.6 * * *$ & & \\
\hline & $\mathrm{BE}$ & CG & 12.01 & 1.27 & 0.24 & 131 & $5094 * * *$ & & \\
\hline Shuttle running & $\mathrm{AE}$ & $c 0$ & 11.86 & 1.25 & 0.23 & 1.31 & 30.94 & 157 & $204 *$ \\
\hline $4 \times 9$ m. (s) & $\mathrm{BE}$ & $E G$ & 11.44 & 1.27 & 0.24 & 271 & $1128 * * *$ & 1.51 & 2.04 \\
\hline & $\mathrm{AE}$ & EG & 11.13 & 1.24 & 0.27 & 2.14 & 41.28 & & \\
\hline Tilts of torso & $\mathrm{BE}$ & $C G$ & 6.52 & 3.26 & 0.61 & 110 & $05 * * *$ & & \\
\hline forward from & $\mathrm{AE}$ & CO & 7.11 & 3.24 & 0.60 & 11.00 & 4.03 & 061 & $231 *$ \\
\hline sitting position & $\mathrm{BE}$ & EG & 5.90 & 3.82 & 0.83 & 59.57 & $13.02 * * *$ & 0.01 & 2.31 \\
\hline$(\mathrm{cm})$ & $\mathrm{AE}$ & EG & 9.58 & 4.06 & 0.89 & 59.51 & 13.02 & & \\
\hline
\end{tabular}

Note: $\mathrm{BE}$ - before the experiment. $\mathrm{AE}$ - after the experiment;

$*$ - The differences are significant at $p<0.05$

$* *$ - The differences are significant at $\mathrm{p}<0.01$

$* * *$ - The differences are significant at $\mathrm{p}<0.001$

\section{Discussion}

The results of our study confirmed the data [16] studies of physical fitness and the manifestation of the relationship of individual motor performance with health indicators. We supplemented the authors' opinion on the role of aerobic performance in the adaptation of boys to different types of physical activity. In this regard. the focus on the lessons in the initial period should be paid to the development of general endurance. which increases the non-specific resistance of the body to adverse environmental conditions.
The results of endurance testing in CG boys are adequate ( 3.7 points) and indicate that boys have a slight growth rate $(0.03 \%)$. The rate of endurance increase in the EG boys is better (3.1\%), the level of development is estimated to be "good". There is a statistical difference $(\mathrm{p}=0.017 ; \mathrm{t}=2.19)$ of the 1000 $\mathrm{m}$ running results after the first year of training [15].

Table 4 
years. then we will get low and medium level of students' readiness [21. 22, 23].

The facts described in the paper correspond to the known ones in the literature [24, 25, 26], but obtained for the students engaged only in physical education at school and those attending sports circles significant statistical material and coverage of extremely important for the entire ontogeny of the age period (10-12 years ) allows you to talk about the materialities of the identified patterns. which require further clarification. First of all. it is a deeper. on the basis of an ever-increasing database. the study of the differences between the central indexes of body mass index of children of Kharkiv region and WHO standards. Secondly. it is necessary to search for formalized data describing the parameters of training during physical education and educational conditions in which children of certain cities and districts of the region live. which will allow to identify the degree of dependence of the parameters of growth and development of students on external factors. Thus. the study confirmed the findings of several authors that in boys 10-12 years of ontogeny period functional capacity of the organism is increasing rapidly. but its ability to adapt to physical activity of different directions is reduced [27, 28, 29]. The growth rate of the results of physical fitness of boys engaged only in physical education at school is due to the natural growth and growth of natural activity. and the students attending sports circles due to the effective use of the forces of nature and exercise [30. 31].

Further ways of solving the problem under study are envisaged in the direction of developing a karate training program. taking into account the adaptation to school education (intellectual. emotional. communication. motivational and physical readiness).

The data obtained indicate a high enough value of karate training for the adaptation of children to physical activity.

\section{Conclusions}

Thus, the results of the basic experiment clearly confirm the hypothesis that a program of karate training. taking into account the functional and physical fitness will allow to develop suitable training programs. the introduction of which in the training process in the associations of additional education (circles. sports ) and to promote the development of adaptive reactions in students engaged in karate from 10-12 years. to the influence of physical activity.

\section{Acknowledgements}

The previous one was carried out on a regular basis to the plan of science-based works of the department of Olympic and professional sports and the institute of physical education and sports of the state institution of Taras Shevchenko Lugansk national university.

\section{Conflict of interest}

Authors state no conflict of interest.

\section{References}

1. Platonov V. Adaptation in sports. Kiev,1988.257p.(In Ukr.).

2. Kyokushinkai Karate Curriculum (Initial Level). Approved by the Scientific and Methodological Commission on Extracurricular Education of the Scientific and Methodological Council for Education of the Ministry of Education and Science of Ukraine,2015.150p.(In Ukr.).

3. Bulich E, Muravov I. Human health. Olympic literature,2003;175p.(In Rus.).

4. Volkov L. Physical abilities of children and adolescents.1981;5(2):116.

5. Vilchkovsky E. Theory and methodology of physical education of children of preschool age University Book. 2008:428p.(In Ukr.).

6. Order of the Ministry of Health of Ukraine. On improvement of medical care for students of general educational institutions. Amended by the Ministry of Health Order. 2012;(382):156.

7. Tikhvinsky S. Children's sports medicine, 1980.560p.(In Rus).
8. Denisova L. Measurement and methods of mathematical statistics in physical education and sports. 2008;(9):127.

9. Physical education curriculum for general educational institutions of grades 5-9 approved by the order of the Ministry of Education and Science № 1407 of 23.10.2017.

10. Tests and standards for annual assessment of physical fitness of the population of Ukraine. http://zakon2.rada.gov.ua/laws/show/z0195-17.

11. Aleksandrov A. Increased blood pressure in childhood and adolescence (juvenile arterial hypertension) Russian Medical Journal.2000;5.(9):559-564.

12. Baevsky RM. Prediction of conditions on the verge of norm and pathology.Medicine.Moscow, 1979.298p.(In Rus.).

13. Zvezdina I. Functional state of the cardiovascular system of children in the dynamics of learning in elementary school. Russian Pediatric Journal. 2009;(2):19-23. 
14. Trofimenko V, Romanyshyna O, Anichkina O, Ivanchuk M, Bohdanyuk A, Zoriy Y, Moseichuk Y,et al. Analysis of the dynamics of physical development and functional state of 9-12-year-old schoolchildren playing volleyball. Journal of Physical Education and Sport. 2019;19(1):748-455.

15. Andrieieva O, Hakman A, Balatska L, Moseichuk Y, Vaskan I, Kljus O. Peculiarities of physical activity regimen of 11-14-year-old children during curricular and extracurricular hours. Journal of Physical Education and Sport. 2017;(17):2422-2427.

16. Procedure for conducting annual assessment of physical fitness of the population of Ukraine. Approved by the Resolution of the Cabinet of Ministers of Ukraine. 2015;104p.(In Ukr.).

17. Krutsevich T. Research methods of individual health of children and adolescents in the process of EF. 1999.230p.(In Rus.).

18. Lapitskaya E, Yatsky Yu. A study of the physical performance of schoolchildren in the Kola Arctic. Physical Culture. Sports and health.1998;7(2):217.

19. Lyakh V. Sensitive periods of development of coordination abilities of children at school age. Theory and practice of physical culture. 2000(3):15 - 19 .

20. Solodkov A. Human physiology. The total. Sports,2001.520 p.(In Rus).

21. Adaptation and cognitive testing of physical activity measures for use with young. school-aged children and their parents. 2012;21(10):1815-1828. doi: $10.1007 / \mathrm{s} 11136-011-0095-1$.

Information about the authors

Kyrpenko Y.V.

http://orcid.org/0000-0002-4009-5070

kirpenko.evgeniy@gmail.com

Ivan Kozhedub Kharkiv National Air Force University

Oboronna st. 2. Starobelsk. 91000

\section{Budur M.I.}

http://orcid.org/0000-0003-1151-777X

stals1212@gmail.com

Ivan Kozhedub Kharkiv National Air Force University

Sumska st. 77/79. Kharkiv. 61023

\section{Palevych S.V.}

http://orcid.org/0000-0002-8304-1857

junpolpsv@gmail.com

Ivan Kozhedub Kharkiv National Air Force University

Sumska st. 77/79. Kharkiv. 61023

\section{Poddubny O.G.}

http://orcid.org/0000-0002-4009-5070 poddubnyag@gmail.com

Ivan Kozhedub Kharkiv National Air Force University Sumska st. 77/79. Kharkiv. 61023

Received: 01.11.2019
22. Andrieieva O. Health status and morbidity of children 11-14 years of age during school. Journal of Physical Education and Sport .2018:21(10):1231-1236.

23. Bodnar I, Dukh T, Martyniv O, Hoshovska L. Can integrative physical education improve physical development of schoolchildren. With a kind of emptiness. Physical Activity Review.2018;(6):1-7.

24. Galan Y, Andrii K, Yuriy M, Paliichuk Y, Moroz O, Tsybanyuk O, et al. Characteristics of physical conditions of 7-9-year-old schoolchildren within the process of physical education. Journal of Physical Education and Sport. 2018;18(5):1999-2007.

25. Krusevich TYu, Vorobyov MI, Bezverkhnya MM. Control in the physical education of children. adolescents and young people. 2011;3(111):224.

26. Pasichnyk V, Pityn M, Melnyk V, Karatnyk I, Hakman A, Galan Y. Prerequisites for the physical development of preschool children for the realization of the tasks of physical education. 2018(6):117-126.

27. Tabachnick B. G. Using Multivariate Statistics. 2007.14p.

28. Harold W.Kohl. III and Heather D. Cook Taking Physical Activity and Physical Education to School, 2013.385p.

29. Tomenko O, Kirichenko L, Skripka I, Kopytina Y, Burla A. Effect of recreational taekwondo training on musculoskeletal system of primary school age children. Journal of Physical Education and Sport. 2017;17(3):1095-1100.

\section{Інформація про авторів}

Кирпенко Є.B.

http://orcid.org/0000-0002-4009-5070

kirpenko.evgeniy@gmail.com

Луганський національний університет ім. Т.Г.

Шевченко

вул. Оборонна 2. Старобільськ. 91000

\section{Будур М.I.}

http://orcid.org/0000-0003-1151-777X

stals1212@gmail.com

Харківський національний університет Повітряних

Сил імені Івана Кожедуба

вул. Сумська 77/79. Харків. 61023

\section{Палевич С.В.}

http://orcid.org/0000-0002-8304-1857

junpolpsv@gmail.com

Харківський національний університет Повітряних Сил імені Івана Кожедуба

вул. Сумська 77/79. Харків. 61023

\section{Піддубний О.Г.}

http://orcid.org/0000-0002-4009-5070 poddubnyag@gmail.com

Харківський національний університет Повітряних Сил імені Івана Кожедуба вул. Сумська 77/79. Харків. 61023

Принята в редакциюю 01.11.2019 